胆石症に対する総胆管十二指腸側側吻合術後に

胃癌の発生をみた 3 症例

\begin{tabular}{|c|c|c|c|c|c|}
\hline \multicolumn{6}{|c|}{ 和歌山県立医科大学消化器外科 } \\
\hline 青 & 洋三 & 川口＼cjkstart富司 & 湯川 & 裕史 & 植阪 和修 \\
\hline 嶋 & 浩介 & 柿原美千秋 & 上田 & 耕臣 & 佐々木政一 \\
\hline & 寛昭 & 竹井 信夫 & 勝見 & 正治 & \\
\hline
\end{tabular}

\title{
THREE CASES OF GASTRIC CARCINOMA DEVELOPED AFTER SIDE-TO-SIDE CHOLEDOCHODUODENOSTOMY FOR GALLSTONE DISEASE
}

\author{
Yozo AOKI, Tomiji KAWAGUCHI, Hirofumi YUKAWA, \\ Kazunobu UESAKA, Kosuke SHIMADA, Michiaki KAKIHARA, \\ Koshin UEDA, Masakazu SASAKI, Hiroaki KAWASHIMA, \\ Nobuo TAKEI and Masaharu KATSUMI \\ Department of Gastroenterological Surgery, Wakayama Medical College
}

索引用語：総胆管十二指晹側側吻合術，胆石症術後胃癌，胆汁胃内逆流

\section{緒 言}

総胆管十二指腸側側吻合術（以下本術式）は適応を 厳格にさえすればその手術成績は一般にいわれるほど 覀いものではない.これは私達の過去15年にわたる詳 細な追跡調查で明らかになっだ)。本術式施行後に起 こる合併症には，释合不全や上行感染など，われわれ が十分に留意すれば予防できるものと, 綿密な管理と 指導をしても，ある程度やむをえないものとがある。 さしずめ胆汁の胃内逆流による，いわゆる胆汁性胃 炎2は後者に属するものと思われる。われわれは70症 例を経験するらち，3症例の胃癌発生に遭遇した。本 論文ではその 3 症例を紹介し, 本術式と術後の胃癌発 生に関し, 胆汁の胃内逆流の観点から若干の文献的考 察を試みる。

\section{対象と方法}

1. 昭和 46 年 1 月から61年 2 月までに和歌山県立医 科大学消化器外科で本術式を施行した70症例を対象と した.

2. 本術式術後 1 カ月から15年を経過した10症例に 対し術後の胆汁胃内逆流を検索するため, 内視鏡検査

$<1987$ 年 2 月 8 日受理 >別刷請求先：青木 洋三

干640 和歌山市 7 番丁 1 和歌山県立医科大学消化 器外科
と胆道シンチグラフィー（以下シンチ）を施行した。 内視鏡検査には原則としてオリンパス社製 GIF-XQ $\mathrm{XQ}_{10}$ を用い, 胆汁の逆流の有無を肉眼的に確かめるととる に, 可能な症例では胃前庭部, 体部, 噴門部より生検 L，10\%ホルマリンで固定後へマトキシリン・エオジ ン染色をして, 胃资や他の病变の有無, 程度を検索し た. シンチは青木ら の方法で行い, 胃領域での放射能 活性の有無により, 胆汁の胃内逆流の有無を推定した.

$$
\text { 結果 }
$$

I. 胃癌発生症例

症例 1.58歳の男性で心窩部痛を主訴として来院し た. 昭和 50 年 6 月 2 日総胆管結石症のため, 胆要摘出 術（以下胆摘）と本術式を弓けた。その後経過は順調 であったが，昭和57年 1 月初旬より空腹時の心窩部痛 を自覚し，同年 2 月 3 日当科を受診，胃癌と診断され た.同年 2 月 24 日胃切除術と所属リンパ節郭清術, Roux-Y 法が施行された。図 1 に術前の胃 $\mathrm{X}$ 線造影 像, 内視鏡像と摘出標本を示す。摘出標本の病理組織 は胃癌取扱い規約4)でい 5 moderately differentiated tubular adenocarcinoma $\left(\mathrm{P}_{0}, \mathrm{H}_{0}, \mathrm{n}(-), \mathrm{pm}, \mathrm{INF} \alpha\right.$, $\mathrm{ly}_{1}, \mathrm{v}_{\mathbf{0}}$, ow (一), aw (一)) で, 粘膜下層にリンパろ 胞の增生がみられた。 また非癌部胃粘膜上皮には腸上 皮化生が認められ, 粘膜の萎縮傾向が強度にみられた 
図 1 症例 1 の術前の胃 X 線造影像（左），内視鏡像（右下）と摘出標本（右下），胃 体下部後壁に病变を認める。
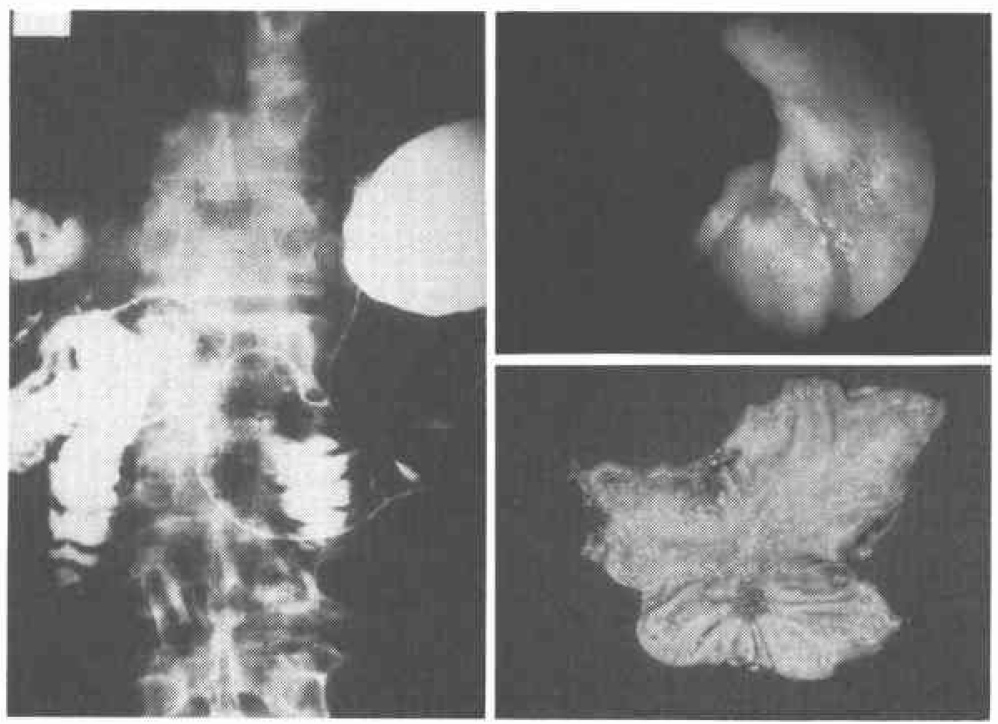

図 2 症例 1 の摘出標本の病理組織像. 病巣に近接し た部の像で, 粘膜の腸上皮化生と萎縮, 粘膜下層に 一部癌の浸潤 (矢印) を認める。へマトキシリン・ エオシンン染色, $\times 25$.

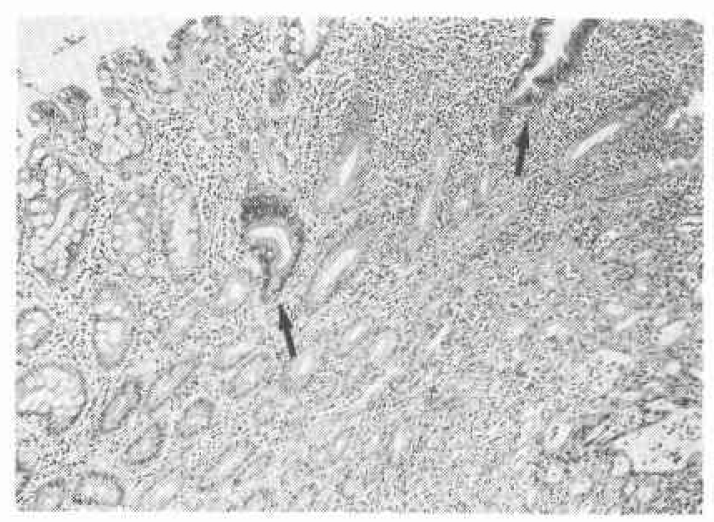

（図 2 ）. 所属リンパ節には転移は認められなかった。 胃切除後 4 年 6 力月を経過した現在, 再発の兆候もな く健在である.

症例 2.72歳の男性で心窩部痛と悪心を主訴に来院 した。昭和 49 年 10 月 31 日胆䪄・総胆管結石のため胆摘 と本術式を受けた。 その後経過は順調であったが，昭 和 58 年 7 月 3 日心窩部痛と悪心を自覚し, 以後悪心が 持続したため, 同年 7 月 14 日当科を受診し胃癌による 幽門狭窄症と診断された。同年 7 月 21 日胃切除術と所
属リンパ節郭清, Billroth II 法再建術をうけた. 摘出 標本の病理組織は mucinous adenocarcinoma $\left(\mathrm{P}_{\mathbf{0}}\right.$, $\mathrm{H}_{0}, \mathrm{n}(+), \operatorname{ss} \gamma, \operatorname{INF} \beta, \mathrm{ly}_{3}, \mathrm{v}_{0}$, ow $\left.(-), \mathrm{aw}(-)\right)$ であった．非癌部胃粘膜上皮は腸上皮化生をともない 萎縮傾向を示していた，10力月後に再発死した。

症例 3.42歳の女性で心窝部痛と食欲不振を主訴に 来院した。昭和 51 年 10 月 25 日胆裹・総胆管結石のため 胆摘と本術式をらけた。その後経過は順調であったが, 昭和60年 7 月ごろから心窩部痛, 8 月より食欲不振が 出現し, 同年10月 2 日勤務先の集団検診で胃の異常を 指摘された。同年10月12日当科を受診し，胃癌と診断 された. 図 3 に当科で施行した胃 X 線バリウム造影像 を示す。胃内視鏡時の生検で signet ring cell carcinoma と診断された．理学的に腹水の眝留とダグラ ス窩転移を認めたため，保存的治療を施行したが10カ 月後死亡した。

II. 本術式術後の胆汁の胃内逆流に関する検討

図 4 にシンチにより観察された本術式術後の胆汁胃 内逆流像を示す。このような胆汁胃内逆流の有無をシ ンチと内視鏡検査の両面から10症例について検討した ところ, シンチでは 3 症例， $30 \%$ に, 内視鏡には 8 症 例，80\%に锤察された(表 1).内視鏡検查時に施行し た生検では，粘膜の炎症像が 5 症例，50\%に，腸上皮 化生が 2 症例，20\%に認められ，生検部位による差は あまりみられなかった（図５）。ちなみに対象とした 
図 3 症例 3 の胃 X 線造影像。胃全体の硬化, 变形々 巨大政譬を認める。

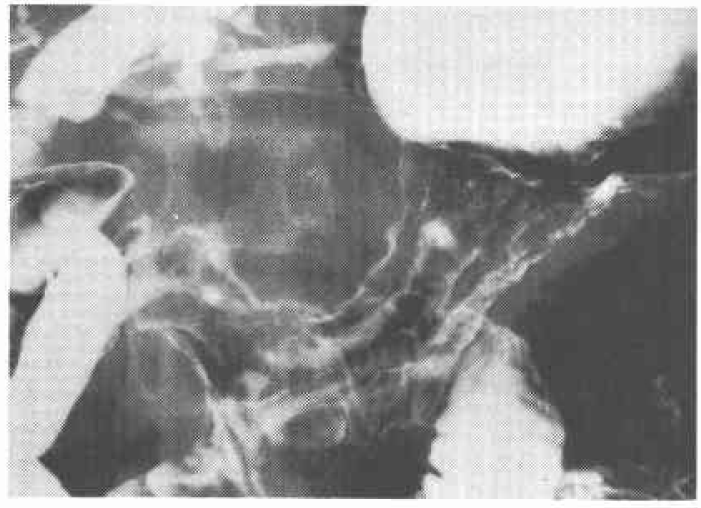

図 4 胆道シンチグラフィーによる胆汁の胃内逆流 （矢印）の証明

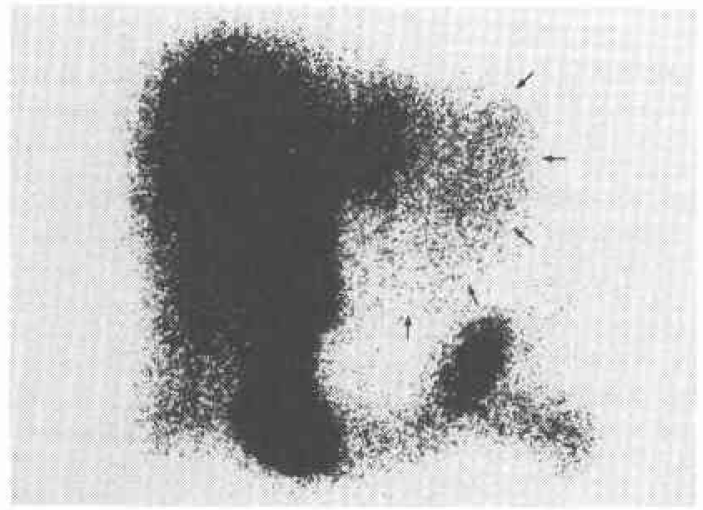

70症例中術前の内視鏡検查時に胆汁の胃内逆流が認め

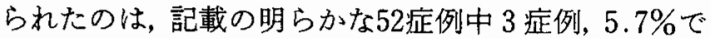
あった。また術後に検討したこれら10症例では術前に は認められていなかった。

\section{考察}

良性疾患に対し本術式がなされた後胃癌が発生した という報告はみあたらない、私達が経験した 3 症例の 内訳は男性 2 症例, 女性 1 症例であり, 術後経過から というと 7 年目が 1 症例, 9 年目が 2 症例である。こ の罹病率を昭和59年度の日本人の胃の悪性新生物によ る死亡率と比較すると明らかに高い5)。すなわち人口

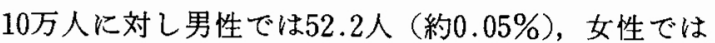
31.1 人 (約 $0.03 \%)$ ，全体で 41.7 人（約 $0.04 \%$ )であり， 手術その他で永久治癒をみた症例を加えたとしても, なおその差は明白である。

本術式と術後の胃癌の発生の関係は不明で推測の域
表 1 胃内視鏡と胆道シンチグラフィーによる 胆汁胃内逆流の観察

\begin{tabular}{|c|c|c|c|c|c|}
\hline \multirow{2}{*}{ 症例 } & \multirow{2}{*}{$\begin{array}{l}\text { 年齡 } \\
\text { (歳) }\end{array}$} & \multirow{2}{*}{ 性 } & \multirow{2}{*}{$\begin{array}{l}\text { 術後 } \\
\text { 経過 } \\
\text { 年月月 }\end{array}$} & \multicolumn{2}{|c|}{ 胆汁胃内逆流* } \\
\hline & & & & 内視鏡 & $\begin{array}{l}\text { シンチグ } \\
\text { ラフィー }\end{array}$ \\
\hline 1 & 74 & $\mathrm{~F}$ & 1 力月 & $(+)$ & $(-)$ \\
\hline 2 & 68 & M & 2 年 & $(-)$ & $(-)$ \\
\hline 3 & 81 & M & 10年 & $(+)$ & $(-)$ \\
\hline 4 & 63 & M & 2 力月 & $(+)$ & $(+)$ \\
\hline 5 & 78 & M & 4 年 & $(+)$ & $(-)$ \\
\hline 6 & 68 & $F$ & 2 年 & $(-)$ & $(-)$ \\
\hline 7 & 52 & $\mathrm{~F}$ & 15年 & $(+)$ & $(-)$ \\
\hline 8 & 42 & $F$ & 10年 & $(t)$ & $(+)$ \\
\hline 9 & 68 & $\mathrm{~F}$ & 3 力月 & $(+)$ & $(+)$ \\
\hline 10 & 65 & $\mathrm{~F}$ & 5 年. & $(+)$ & $(-)$ \\
\hline
\end{tabular}

・両検査で陰性の症例は胃生検所見る正常

図 5 胃内視鏡検査時の生検所見. 表 1 の症例 9. び らんと粘膜上皮下の炎症性細胞浸潤を認める. へマ トキシリン・エオシンン染色, $\times 50$.

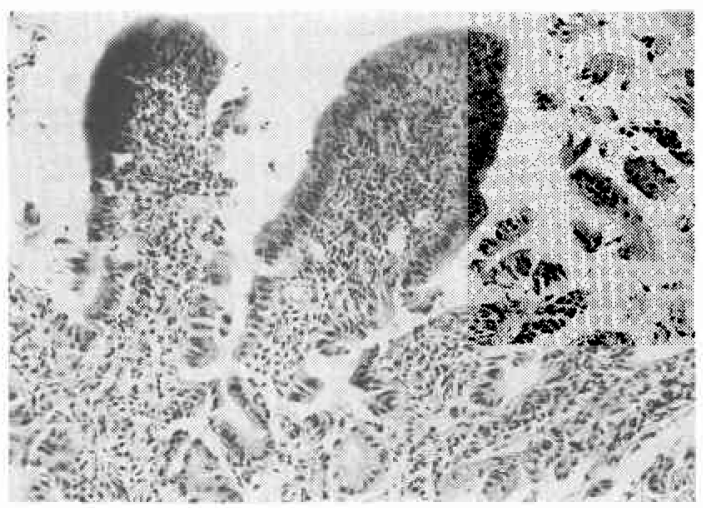

を出ないが，今回の10症例の検討で，シンチでは $30 \%$, 内視鏡検査では $80 \%$ に胆汁の胃内逆流が観察されたこ とから, 以後胆汁の胃内逆流との関連性において考察 をすすめる、シンチでの検出率が $30 \%$ と低いのは，少 量の胆汁が胃に逆流しても胆汁の放射能活性がバック グラウンドのそれに打ち消され，識別不能になる症例 がかなりあるためと思われる、胆汁の胃内逆流による 胃癌の発生は, 胃切除後の残胃でのものでよく知られ ている。胃良性疾患に対する胃切除後に発生する残胃

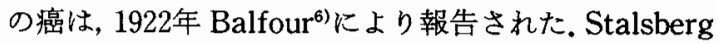
ら”は630例の検討から，25年以上前に胃切除をらけた 群の胃癌死は同年代の胃癌死の 6 倍にのぼると述べて いる. Siurala $5^{8)}$ は胃亜全摘後に発生する残胃の萎縮 性胃炎は小腸との吻合部近傍で最も著しく，かつこの 
部に発癌しやすいことから, 胆汁の逆流が胃粘膜障害, ひいては発癌の重要な要因となることを指摘した。 ラットを用いた実験によれば，胃切除後 Billroth II 法 で再建した群で残胃での発癌率が最も高く ${ }^{9)}$, Billroth I 法再建がこれにつぎ, Roux-Yによるものがもっとも 低率であった。これらの事実は臨床的にも一致するこ とから ${ }^{10)}$, 残胃内に逆流した胆汁が残胃での発癌に一 役をにならことは確実であろう。

さて本術式の術後には胆汁の胃内逆流が高頻度に起 こることは文献的にも散見され゙1), 今回の検討からも 明らかになった。この理由は明らかでないが，われわ れは，(1) 本術式施行時の胆摘にともなう胆汁貯留襄 の消失，(2) 十二指腸球部での総胆管との吻合による 幽門括約筋機能の变化，の 2 点をその原因として想定 した. 胆摘により胆汁は間断なく十二指腸に流出する 結果, 胃内に逆流しやすくなる2).このような見地から 胆摘と胃癌発生との関係が検討されている. Gustavsson ら ${ }^{12}$ は $12 〜 15$ 年前に胆摘をうけた 16,773 症例につ き胃癌の罹病率を検索したところ, 術後 1 年以内は有 意に高かったが， 2 年目以降になると期待值と変らな かった. 術後 1 年以内に高かったのは, 胆摘時に既存 の胃癌の見落しによるものであろらとし, 胆摘は必ず しも胃癌になるリスクを高めるものではないと結論し ている。, 一方, Lowenfels ら ${ }^{13)}$ は剖検例での検討から, 若年の女性で胆石症を有するもの，既往に胆摘をらけ ているものに胃癌が好発していたと述べ，その原因に 胆汁の胃内逆流を挙げている。いずれにしても胆摘に より胆汁性胃炎, ひいては胃癌に䍙患するリスクが高 まりらることは䇾告としてらけとらねばならない，加 えて本術式では吻合口が十二指腸球部に存在するた め, 肝から分泌された胆汁の一部が十二指腸乳頭部を 経ずここに流入すること，吻合口が幽門括約筇と接し て存在するため，幽門括約筋機能に变化をきたすであ ろらことは容易に想像され，これが胆汁の胃内への逆 流をうながし，胆汁酸による胃粘膜の電気生理学的变 化 ${ }^{14)}$, 胆汁性胃炎 ${ }^{2)}$, 胃内酸度の低下と細菌の増殖 ${ }^{2}$, などが関与して発癌へと進展する症例もありらると思 われる、したがって本術式の術後にはこのようなりス クにも留意し, 長期にわたる観察が必要と考劣る.

\section{結語}

1. 胆石症に対する総胆管十二指腸側側吻合術術後 70 症例の最長 15 年にわたる追跡調查中に 3 症例, $4.3 \%$ に胃癌の発生をみた。

2. 本術式の術後には胆汁の胃内逆流が $30 \sim 80 \% に$
みられることから,これによる発癌の可能性を認識し， 長期観察する必要がある.

な招本論文の要旨は第28回日本消化器外科学会総会（昭 和61年 7 月, 青森市)において発表した。

\section{文献}

1）青木洋三，中塚久仁英，川口富司经か：総胆管十二 指腸側側吻合術の臨床的検討 (第 2 報)。 日臨外医 会誌 $47: 17-24,1986$

2) Buxbaum KL: Bile gastritis occuring after cholecystectomy. Am J Gastroenterol 77 : 305-311, 1982

3）青木洋三，谷口勝俊，勝見正治注か：肝・胆道シン チグラムの定量解析とこれによる胃全摘後 Postcibal Asynchronism の経時的覞察. 日消外会誌 $13: 137-145,1980$

4）胃癌研究会編：外科・病理胃癌取扱い規約. 改訂第 11版，東京，金原出版，1985

5）厚生省大臣官房統計情報部編：昭和59年度人口動 態統計. 上巻, 東京, 財団法人厚生統計協会, 1986 , p216-221

6) Balfour DC: Factors influencing the life expectancy of patients operated on for gastric ulcers. Ann Surg $75: 405-408,1922$

7) Stalsberg H, Taksdal S: Stomach cancer following gastric surgery for benign conditions. Lancet 2 : 1175-1177, 1971

8) Siurala M, Isokoski M, Varis $\mathrm{K}$ et al: Prevalence of gastritis in a rural population. Scand $\mathrm{J}$ Gastroenterol $3: 211-223,1968$

9) Kondo K, Suzuki H, Nagayo T: The influence of gastrojejunal anastomosis on gastric carcinogenesis in rats. Gann $75: 362-369,1984$

10) Domellöf $L$, Janunger KG: The risk for gastric carcinoma after partial gastrectomy. Am J Surg $134: 581-584,1977$

11) Akiyama H, Ikezawa $H$, Kameya $S$ et al: Unsuspected problems of external choledochoduodenostomy. Fiberscopic examination in 15 patients. Am J Surg 140:660-665, 1980

12) Gustavsson S, Adami HO, Meirik $O$ et al: Cholecystectomy as a risk factor for gastric cancer. A cohort study. Dig Dis Sci 29 : 116-120, 1984

13) Lowenfels $A B$, Domellöf $L$, Landström $C G$ et al: Cholelithiasis, cholecystectomy and cancer: A case control study in Sweden. Gastroenterology $83: 672-676,1982$

14) Silen W, Forte JG: Effects of bile salts on amphibian gastric mucosa. Am J Physiol 228 : 637-644, 1975 